\title{
Attenuator Device
}

National Cancer Institute

\section{Source}

National Cancer Institute. Attenuator Device. NCI Thesaurus. Code C49830.

An electrical device designed to reduce the strength of a signal. 